\title{
Merkezîleşme Politikaları Sürecinde Yurtluk-Ocaklık Sisteminin Değişimi
}

\author{
Alteration of the Yurtluk-Ocaklık System in the Process of \\ Centralization Policies
}

Fatih GENCER*

$\ddot{O} z$

I. Selim zamaninda uygulanmaya konmuş olan yurtluk-ocaklik sistemi 19. yüzylla gelindiğinde tamamen işlevini yitirmişti. Bu nedenle Tanzimat'ın hayata geçirilmesiyle birlikte başlayan merkezîleşme politikaları sürecinde yurtluk-ocakllk sistemi yeniden düzenlenmişti. Bu amaçla ilk önce doğu eyaletlerindeki güçlü beylerin tamamı bölgeden uzaklaşttrılmıştı. Bundan sonra bu beylerin asıl güç kaynağı olan yurtluk-ocaklıklara devlet tarafinda el konularak karşıllğında bunlara bir miktar maaş bağlanmış ve devlete bağımlı hale getirilmişslerdi.

Anahtar Kelimeler : Yurtluk-Ocaklık, Merkezîleşme, Kürt Beyleri

\section{Abstract}

The system of yurtluk-ocakllk which was set to implement during the reign of Selim I, completely lost its function in the $19^{\text {th }}$ century. This system was therefore regulated in the process of centralization policies which started with Tanzimat. For this purpose, firstly, all the powerfull notables in the eastern provinces were moved away from these areas. Afterwards yurtluk-ocaklik, which was the real source of power for these powerful notables, was confiscated and, they were put on a salary and became dependent on state

Keywords: Yurtluk-Ocaklı, Centralization, Kurdish Notables

\footnotetext{
* Araştırma Görevlisi Dr., Yüzüncü Yll Üniversitesi Edebiyat Fakültesi Tarih Bölümü, gencer@yyu.edu.tr.
} 
Osmanlılar fethettikleri bölgelerin durumuna göre mutlak bir merkezîyetçilik fikriyle hareket etmemişler, pragmatik davranarak ihtiyaca göre farklı özelliklere sahip çeşitli idare şekilleri tesis etmişlerdi ${ }^{1}$. Bu anlayışın sonucu olarak Adana ${ }^{2}$, Çıldır ${ }^{3}$, Trabzon, Şam, Rakka, Tunus, Bosna, Şehrizor ${ }^{4}$ ve daha çok İran sınırına yakın bölgelerde, Ekrâd sancağı (Yurtluk-Ocaklık) ve hükümet diye adlandırılan bir tür irsî sancak beylikleri oluşturmuşlardı ${ }^{5}$. Büyük ölçüde yerel hanedanların, özellikle Kürt beylerinin nüfuzundan faydalanmaya dayanan bu idari sistem, Yavuz Sultan Selim'in talimatları doğrultusunda hareket eden İdris-i Bitlisî'nin öncülüğünde gerçekleştirilmiştí

Hükümet ve Ekrâd sancaklarının varlığına müsaade edilmesinin başlıca nedeni yeni fethedilmiş olan Fırat Nehri'nin doğusundaki toprakları merkezî otoriteye bağlamaktı ${ }^{7}$. İmparatorluk ordusunun seferber edilmesinin maliyetinin yüksek olduğu bu dönemde, bu idare biçimi hem etkili hem de ekonomikti ${ }^{8}$.

Hükümet ve Ekrâd sancakları ocaklık yoluyla tasarruf edilirlerdi. Ocaklık ise hizmet karşılığ oğla miras kalmasıydı ${ }^{9}$. Bu sistemden yararlanan biri, suç işleyip idam cezasına çarptırılsa bile sahip olduğu hakların tamamı oğluna miras kalırdı ${ }^{10}$. Ancak arazisini satamaz, bağ

1 Serafettin Turan, “XVII. Yüzyılda Osmanlı İmpratorluğu'nun İdari Taksimatı”, Atatürk Üniversitesi 1961 Ylllı̆̆g, Erzurum 1963, s.201; Mehmet Öz, XVI. Yüzyılda Bitlis Sancağ1: Yönetim, Nüfus ve Vergilendirme", IX $X^{\text {th }}$ International Congress Of Economic And Social History Of Turkey, T.T.K., Dubrovnik 2002, s. 31.

2 Yılmaz Kurt, XVI. Yüzyılda Adana Tarihi, Basılmamış Doktora Tezi, Hacettepe Üniversitesi Sosyal Bilimler Enstitüsü, Ankara 1992, s.27.

3 M.H. Svanidze, “Ahısha (Çıldır) Eyaleti'nde Defter-i Caba-i (1694-1732) Verilerine Göre Timarların Yıllık Gelirleri”, XII. Türk Tarih Kongresi, III, Ankara 1999, s.866.

4 Ömer Toraman, Tanzimat'ın Yurtluk-Ocaklık ve Hükümet Sancaklarında Uygulanması (1839-1864), Basılmamış Doktora Tezi, Fırat Üniversitesi Sosyal Bilimler Enstitüsü, Elazığ 2010, s.6.

5 Orhan Kılıç, "Yurtluk-Ocaklık ve Hükümet Sancaklar Üzerine Bazı Tespitler”, OTAM, Say1 10, Ankara 1999, s.119; Mehmet Ali Ünal, "Osmanlı Devleti'nde Merkezi Otorite ve Taşra Teşkilatı”, Osmanlı, 6.Cilt, Yeni Türkiye Yayınları, Ankara 1999, s.117.

6 Bayram Kodaman, Osmanlı Devrinde Doğu Anadolu'nun İdari Durumu, Anadolu Basın Birliği Yayınları, Ankara 1986, s.13.

7 Orhan Kılıç, a.g.m., s.122.

8 David McDowall, "Kürt Sorunu: Tarihsel Bir Bakış", Kürtler, Ed. Philip G. KreyenbroekStefan Sperl, (Çev. Yavuz Alagon), Cep Kitapları, İstanbul 1992, s. 18

9 Sofyalı Ali Çavuş Kanunnâmesi Osmanl Imparatorluğu'nda Toprak Tasarruf Sistemi'nin Hukuki ve Mâli Müeyyede ve Mükellefiyetleri, Hazırlayan Midhat Sertoğlu, Marmara Üniversitesi Yayınları, İstanbul 1992, s.15.

10 Nejat Göyünç, "Yurtluk-Ocaklık Deyimleri Hakkında", Prof. Dr. Bekir Kütükoğlu’na Armă̆an, İstanbul 1991, s. 271.

11 Y1lmaz Kurt, a.g.e., s.27. 
Gerek kanunnâmelere, gerekse bu sistem üzerine yapılan çalıșmalara göre iki sancak şekli arasındaki temel fark tahrire tabi olup olmamadan ileri gelmekteydi. Ekrâd sancakları tahrire tabi olduğundan içinde tımar erbâbı bulunurdu $^{12}$. Hükümet sancakları ise beylerine mülkiyet yolu ile verilmiş olduğundan tahrire tabi olmayıp içinde tımar ve zeameti barındırmazlardı. Bunlar "mefrûzü'l-kalem ve maktûü'l-kadem" (sayım yapılmayan ve Osmanlı yöneticilerinin müdahale etmediği) olduklarından sancağın gelirlerinin tamamı yöneticilerine aitti ${ }^{13}$. Hem hükümet hem de Ekrâd sancağının beyleri bağlı oldukları beylerbeyi ile seferlere katılmak zorundaydılar ${ }^{14}$. Görevlerini yerine getirmezlerse azledilirler ve sancak oğullarından veya akrabalarından uygun görülen birine verilirdi. Değişiklik teklifi beylerbeyinin arzı ile Divan-1 Hümayunda görüşülür, uygun görüldüğü takdirde teklif edilen şahıs sancağa yönetici olarak atanırd ${ }^{15}$.

Kanuni döneminde Diyarbakır Eyaleti'nde Cizre, Eğil, Genç, Palu, Hazro olmak üzere beş hükümet, sekiz de yurtluk-ocaklık sancağı bulunmaktayd1 ${ }^{16}$. Ancak Osmanl1-Safevi rekabeti nedeniyle bu tarz sancakların sayısının zamanla arttığı gözlemlenmiştir ${ }^{17}$.

$\mathrm{Bu}$ tarz sancakların beyleri görevleri gereği Osmanl1-İran savaşlarının tamamına katılmışlardı. Bunlar savaşlarda gösterdikleri cesaret ve kahramanlıkla daima ön planda yer almışlardı. Zaten yaşadıkları coğrafya ve edindikleri hayat tarzı gereği bu gibi özelliklere sahip olmak zorundaydılar. Nitekim Şerefnâme'de ifade edildiğine göre 1578 yılındaki Gürcistan ve Şirvan seferine katılan Kürt beyleri, kendilerini bilerek ölüme atarcasina savaşmışlardı. Bu yüzden Cizre Hâkimi Mir Mehmet, Hazro Hâkimi Saruhan Bey, Zirki Beyi Duman Bey ve Finikli Mir Mehmet savaş meydanında hayatlarını kaybetmişlerdi ${ }^{18}$.

Dönemin teknolojik ve ekonomik şartları göz önüne alındığında sınır bölgelerinin muhafazası için böyle bir sistemin oluşturulması zorunluydu. Ancak bu sistemin iyi bir şekilde işlemesi devletin gücü ile de doğru orantıllydı. Devletin güçlü olduğu dönemlerde bölgedeki beyler merkezî

12 Ayn-1 Ali Efendi, Kavânîn-i Âl-i Osman der Hülâsa-i Mezâmin-i Defter-i Divan, (Haz. M. Tayyib Gökbilgin), Enderun Yayınları, İstanbul 1979, s.29-30.

13 Ayn-1 Ali Efendi, a.g.e., s.30; Mehmet Öz, a.g.b., s.36.

14 Sofyalı Ali Çavuş Kanunnâmesi, s.19.

15 Nejat Göyünç, “Osmanlı Devleti'nde Taşra Teşkilatı (Tanzimat'a Kadar)”, Osmanlı, 6.Cilt, Yeni Türkiye Yayınları, Ankara 1999, s.85; Bayram Kodaman, a.g.e, s.20-21; Mehmet Öz, a.g.b., s. 37; Ayn-1 Ali Efendi, a.g.e.,s.29-30;

16 Evliya Çelebi, Evliya Celebi Seyahatnamesi, 4. Cilt, Dersaadet İkdam Matbaası, 1314, s.27

17 Mehmet Öz, a.g.b., s.37-38.

18 Şerefhan, Şerefname Kürt Tarihi, (Çev. M. Emin Bozarslan), Hasat Yayınları, İstanbul 1990, s.152. 
yönetimin buyruklarına itaat etmişlerdi. Ancak merkezî otoritenin gücünü yitirmesiyle birlikte bu sistemde de çeşitli sorunlar ortaya çıkmaya başlamıştı. Özellikle 19. yüzyılın başlarında bu tarz sancakların beyleri başına buyruk hareket eder hale gelerek görevlerini yapmamaya başlamışlardı. Örneğin yüzyılın başlarında sefere katılması emredildiği halde, dönemin Cizre Beyi seferden affinı isteyecek duruma gelmişti ${ }^{19}$. Bu dönemde söz konusu beylerin devlete bağlılığ sadece kâğıt üzerinde olduğundan 1828-1829 Osmanl1-Rus Harbi'ne Bohtan, Revanduz, Baban ve Hakkâri beyleri katılmamışlard ${ }^{20}$. Savaşın yıkıcı sonuçları bu sözde bağlığı da tamamen ortadan kaldırmış ve Bağdat ile İstanbul arasındaki bağlantı kesilmişti ${ }^{21}$. Böylece Sivas'tan, İran ve Arabistan hudutlarına kadar olan bölgenin önemli bir kısmı fiilen Kürt beylerinin denetimine geçmişti ${ }^{22}$.

İncelediğimiz belgelerden anlaşıldığı kadarıyla, 19. yüzyılın başlarında fiilen varlığını sürdürmekle birlikte, hükümet sancağı tabiri artık kullanılmamaktaydı. Aslında topraktan yararlanma şeklini ifade eden yurtluk ve ocaklık tabiri genel olarak bu sistemi ifade eder hale gelmişti. Örneğin 1737 tarihinde Hükümet-i Hakkâri tabiriyle Tahvil Kalemi'nde kayıtlı olduğu belirtilen Hakkâri Sancağı, 1827 tarihinde yurtluk-ocaklık olarak tanımlanmıştı ${ }^{23}$. Aynı şekilde Kanuni döneminde hükümet olarak tanımlanan Palu Sancağı, 1841 yılında mülknâmesi yenilenirken bu kez yurtluk-ocaklık olarak ifade edilmişti $\mathrm{i}^{24}$. Ayrıca Mehmet Hurşit Paşa, yurtluk-ocaklıkları tarif ederken, bir bölgenin yurtluk-ocaklık şekliyle mutasarrıfının bulunması durumunda devletin oraya müdahale edemediğini ve bu durumun vazifelerin yapılmasına engel teşkil ettiğini dile getirmişti ${ }^{25}$. Dikkat edilirse bu tanım klasik dönem hükümet sancaklarını ifade etmekte ve aynı zamanda bizim konu ile ilgili kanaatimizi doğrulamaktadır.

Yurtluk-ocaklıklar genellikle sarp dağlık bölgelerde yani Palu'dan başlayarak Diyarbakır'ın dağlık bölgelerinin önemli bir kısmı ile Bitlis, Muş,

19 BOA, HAT, 272/15927, 29.Z.1217 (1802).

20 Michael Eppel, "The Demise of the Kurdish Emirates: The Impact of Ottoman Reforms and International Relations on Kurdistan during the First Half of the Nineteenth Century", Middle Eastern Studies, Vol. 44, No. 2, March 2008, s.247.

21 P. Averyanof, 19. Asırda Rusya, Türkiye, Iran Muharebeleri Türk-Irran-Rus Kürtlerinin Vaziyet-i Hazıraları, (Çev. Yüzbaşı Mustafa Efendi-Mülazım Adil Efendi), Hâkimiyet-i Milliye Matbaas1, Ankara 1926, s. 44.

22 A. B. Cunningham (Ed.), The Early Correspondence Of Richard Wood (1831-1841), London 1966, s.93.

23 BOA, HAT, 770/36176, 17 B. 1242 (14 Şubat 1827).

24 BOA, İ.MVL 237/8388-2, 1 L.1257 (16 Kasım 1841).

25 Mehmed Hurşid Paşa, Seyâhatnâme-i Hudûd, Çevrimyazı Alaattin Eser, Simurg Yayınları, İstanbul 1997, s.241. 
Van, Hakkâri, Bayezid ve Çıldır gibi yerlerde yoğunlaşmışlardı. Yurtlukocaklık sahibi beylerin aslında Osmanlı idari sistemi içerisindeki resmi yetki alanları oldukça dardı. Ancak fiiliyatta durum bunun tam tersiydi. Bunlar yüzyıllardır varlığını sürdüren hanedanlara mensuplardı. Bu nedenle bölge halk1 üzerinde önemli ölçüde nüfuz sahibi olmuşlardı. Özellikle göçebe aşiretleri hükümleri altına alıp bunların askeri gücünden faydalanıyorlardı.

Bölgedeki ahali, özellikle Kürt aşiretleri, beylerine son derece bağlıydılar. Bu bağlılığın aynı zamanda manevi bir yönü de bulunmaktaydı. Mesela Cizre Beyi Seyfettin'in Halit bin Velid'in soyundan geldiğine inanılıyordu. Bunlar gittikleri her yerde saygı görür, bölge halkı kadın-erkek toplanarak eteklerine kapanıp ellerini öperlerdi. Sahip oldukları nüfuz sayesinde aşiretler arasındaki çatışmalara son verdikleri gibi yeni bir savaşı da başlatabilirlerdi ${ }^{26}$. Bu beyler devletin bölgede fiilen var olmasını istemediklerinden vergi ve asker toplanmasına her zaman karş1 çıkmışlardı ${ }^{27}$. Ayrıca gerektiğinde sığınmak için genellikle sarp ve dağlık bölgelere çok sağlam kaleler yaptırmışlardı ${ }^{28}$. Ahali üzerindeki nüfuzları ve sahip oldukları imkânlar onların günden güne daha çok güçlenmelerini sağlıyordu.

Osmanl1-İran sınır bölgesinde bulunan yurtluk-ocaklık sahibi beyler bazen zorla da olsa İran'a tabi olmuşlard1. Mesela İranlılar H.1238 (18221823) senesinde Hakkâri bölgesinde bulunan Somalı ve Biradost'a asker sevk ederek bölgedeki ileri gelenleri ele geçirmişlerdi. Böylece bunların sahip oldukları topraklar da fiilen İranlıların denetimine geçmiş oluyordu. Bölgede o dönemde hiçbir Osmanlı memuru bulunmuyordu. Ayrıca Kürtlerin, askerin bölgeye gelmesini istemeyip susması nedeniyle bu durumun anlaşılması da epey zaman almışt ${ }^{29}$. Öte yandan beylerin sorumsuz davranarak kanunlara aykırı olmasına rağmen yurtluk-ocaklıklarını İranlılara sattıkları da olmuştu ${ }^{30}$. Örneğin Mahmudi Beylerinden Musa Bey çok fazla borçlanmış ve borçları karşılığında üzerinde olan köylerin çoğunu İranlılara satmıştı. Ayrıca bir kısım köylerini de hizmetkârlarına vermişti. Bunlar da ellerinden alınır korkusuyla bu köyleri İranlılara satmıştı. Bu şekilde Kotur nahiyesinin bütün köyleri yani; Kötnevar, Ruyuvan, Geveran, Tersava, İstiran, Şekeryazı, Genzelehuk, Habeş-i Ulya, Habeş-i Süfla, Ketl, Mehin, Ziri, Kükürt, Kaşkabulak, Elmalı, Gayelik, Hindivan, Piranoğlu İranlıların eline geçmişti. Böylece Osmanlı Devleti, sınırları içerisinde bulunan bir

${ }^{26}$ BOA, HAT, 288/17298-G, 21 M.1252 (8 May1s 1836).

27 Helmuth Von, Moltke, Moltke'nin Türkiye Mektuplarl, (Çev. Hayrullah Örs), Remzi Kitabevi, İstanbul 1999, s. 230-231.

28 BOA, HAT, 288/17298-A, 29 Z.1250 (1834).

29 BOA, A.MKT, 206/9, 23 B. 1265 (14 Haziran 1849).

30 BOA, HAT, 812/37250-K, 29 Z.1241 (1825). 
nahiyeyi kaybetmişti ${ }^{31}$. Daha sonra bu durum anlaşıldığında İranlılarla buraların iadesi için müzakereler yapılmış ve İran elçisi gerekirse satış işlemlerinin belgelerini gösterebileceğini yetkililere iletmişti. Bunun nasıl olduğu elçiye sorulduğunda, padişah fermanıyla buralar bizim yurtluk ve ocaklığımızdır, diyerek kendilerine sattıklarını anlatmış ve ödenen paraların iadesi durumunda söz konusu köylerin geri verileceğini belirtmişti ${ }^{32}$. Bu gibi olaylar nedeniyle Osmanlı Devleti'nin sınırdaki toprakları üzerinde İran Devleti hak iddia eder hale gelmişti ${ }^{33}$.

Yurtluk ocaklık sahibi beylerin bu dönemde sahip oldukları toprakları genişletme eğiliminde oldukları gözlemlenmiştir. Mesela yüzyılın başında Muş Mutasarrıfı Selim Paşa Bitlis Beyliği'ni ortadan kaldırmış ve bundan sonra Bitlis onun ailesi tarafından idare edilmişti ${ }^{34}$. Daha sonra akrabalarının yurtluk-ocaklığı olan Hınıs ve Tekman kazalarını zorla alarak kendi üzerlerine geçirmeyi başarmıştı ${ }^{35}$. Ayrıca Selim Paşa, düşmanı olan Adilcevaz ve Ahlat Müdürü Şeyh Ahmet'e saldırmış ve idaresindeki toprakları ele geçirmiş, ${ }^{36}$ bununla da yetinmeyerek Şirvan üzerine yürüyüp köylerini yağmalamışt1 ${ }^{37}$.

Tüm olumsuzluklara rağmen bu sistem bazı zorunluluklar nedeniyle devam etmekteydi. Bir defa bölgenin merkezden atanan memurlar tarafindan yönetilmesi çok zordu. Çünkü buralar genellikle çok sarp ve geçit vermez dağlardan oluşmaktaydı. Ayrıca buralarda yaşayan ahali aşiretler halinde ve genellikle göçebe tarzı hayat sürdürmekteydi. Dolayısıyla buraları idare etmek için bölgeye müstahkem mevkiler kurup, bunların içine çok sayıda asker yerleştirmek gerekmekteydi. Bu askerlerin asayişi sağlama ve vergi toplama gibi işleri yapabilmesi için sürekli hareket halinde bulunması kaçınılmazdı. Ancak Osmanlı merkezî yönetiminin etkisizliği ve bölgenin arazi yapısı göz önüne alındığında böyle bir düşüncenin hayata geçirilmesi neredeyse imkânsızdı. Bu nedenle Osmanlı yönetimi; nüfuz sahibi, aşiretler üstü otoritesi olan, soylarını bir şekilde dini yönü ile ön plana çıkmış şahıslara bağlayan ve halk tarafindan da bu şekilde kabul gören bölgesel

31 Derviş Paşa, Tahdîd-i Hudûd-ı Íraniyeye Me'mûr Derviş Paşa Lâyihası, Matbaa-i Amire, İstanbul 1286, s.124-131.

32 BOA, HAT, 812/37250-A, 19 S. 1241 (3 Ekim 1825).

33 BOA, HAT, 770/36176, 17 B. 1242 (14 Şubat 1827).

34 James Brant-A.G. Glascott, "Notes of a Journey Through a Part of Kurdistán, in the Summer of 1838", Journal of the Royal Geographical Society of London, Vol. 10. (1840), s. 381.

35 BOA, HAT, 819/37339-C, 3 Ş. 1237 (25 Nisan 1822).

36 BOA, HAT, 812/37250-K, 29 Z. 1241 (1825).

37 BOA, HAT, 770/36176-V, 17 C. 1242 (16 Ocak 1827). 
liderler vasıtasıyla buraları idare etmek zorunda kalmıştı. Bu zorunluluğu, Bayezid Sancağı'na Behlül Paşa'nın atanmasıyla ilgili 3 Nisan 1824 tarihli bir belge açıkça ortaya koymaktadır. Buna göre yurtluk-ocaklık üzere verilmiş olan Bayezid sancağının yine aynı şekilde idare edilmesi gerekmekteydi. Bu düşüncenin gerekçeleri sıralanırken, Behlül Paşa'nın o tarafın önde geleni olduğundan bahsedilerek, başka birinin görevlendirilmesi durumunda bölgenin idare edilemeyeceğine dikkat çekilmişti. Öte yandan bir diğer yöneticinin atanması durumunda buraya çok sayıda asker yerleştirilmesi gerektiği ve bunların masraflarının da çok olacağı özellikle belirtilmişti. Söz konusu zorunluluklar nedeniyle eski yönetime müdahale edilmemiş, Behlül Paşa görevine devam etmişti ${ }^{38}$.

Yurtluk-ocaklıkların bölge ekonomisi üzerinde dolaylı ve doğrudan önemli etkileri bulunmaktaydı. Buraların mutasarrıfı olanlar imtiyazlarından faydalanıp vergi ödemeden halkın sırtından bedavaya geçiniyor, bu nedenle devlet ekonomisine önemli ölçüde zarar veriyorlard ${ }^{39}$. Mesela yetkililerin ifadelerine göre yurtluk-ocaklık olan Bayezid Sancağı'ndan vergi alındığı vaki olmamıştı ${ }^{40}$. Ayrıca beylerin hizmetlerinde bulunan çok sayıda kişi, onlardan aldıkları ücretlerle geçimlerini sağlıyordu. Sadece bu boyutuyla ele alınırsa bu sistemin kendi içinde çıkmazlarını yarattığı da söylenebilir. Nitekim yurtluk-ocaklıklara son verilmesi durumunda beyler ve hizmetkârlarının bir anda her şeylerini kaybedeceği, bu durumun belki de önü alınamayacak sosyal tepkilere yol açacağı dönemin raporlarına yansımıştı ${ }^{41}$. Zaten devletin böyle bir girişim için yeterli gücü de yoktu ${ }^{42}$.

Osmanlı yetkilileri, devlet kaynaklarının israf edildiği gerekçesiyle Kürt Beylerinin imtiyazlarından ve bazı sancakların bunlar tarafindan idare edilmesinden hiç de hoşnut değillerdi. Bu konuda da haksız sayılmazlardı. Nitekim topraklarının önemli bir kısmı yurtluk-ocaklık olan Muş Sancağı'ndan Redif-i Mansure için ancak yüz elli bin kuruş toplanabilmişti. Oysa ki Muş'un yıllık geliri iki bin kesenin üzerindeydiª ${ }^{43}$. Yetkililer Kürt beylerinin yerine merkezden atanan memurların görevlendirilmesi durumunda, bölge gelirlerinin doğrudan hazineye akmasının yolunun açılacağını ve bu şekilde devletin güçleneceğini düşünüyorlard ${ }^{44}$.

38 BOA, HAT, 803/37120, 3 Ş. 1239 (3 Nisan 1824).

39 Diyarbekir (Vilayet Gazetesi), Nr.11.

40 BOA, C.DH, 299/14948, 7 B.1261 (12 Temmuz 1845)

41 BOA, HAT, 490/24028-C, 3 Z.1250 (2 Nisan 1835).

42 Sarah D. Shields, Mosul Before Iraq, State University of New York Press, Albany 2000, s.33.

43 BOA, HAT, 533/26254-A, 15 B.1251 (6 Kasım 1845).

44 BOA, HAT, 637/31417-A, 24 C.1252 (6 Ekim 1836). 
$\mathrm{Bu}$ dönemde yurtluk-ocaklık sisteminin düzenlenmesi amacıyla çeşitli raporlar hazırlanarak merkeze sunulmuştu. Mesela Çıldır Beylerbeyi ve Kars Muhafızı Ahmet Paşa, Kars ve Çıldır eyaletleri sınırlarında bulunan bu tarz topraklara, Mansure Hazinesi'nce el konulmasını önermişti. Bu öneriyi değerlendiren yetkililer, böyle bir uygulamanın yürürlüğe konması halinde Erzurum-Van çevresindeki yurtluk-ocaklıklara da el konması gerektiğine dikkat çekmişlerdi. Yurtluk-ocaklık sahiplerinin tek geçim kaynaklarının ellerinden alınması bazı sorunlara sebep olacağından, bu tarz toprakların senelik gelirlerinin üçte ikisinin Mansure Hazinesi'ne gönderilmesini, kalanının da kaydı hayat şartıyla mutasarrıflarına verilmesini tavsiye etmişlerdi ${ }^{45}$. Ancak tepkilerden çekinen Osmanlı yönetimi böyle bir uygulamayı hayata geçirmeye cesaret edememişti ${ }^{46}$. Bu nedenle eski usulün devam ettirilmesine karar verilmişti. Yani yurtluk-ocaklıklar, sahiplerinin ölümü durumunda eyalet valilerinin arzları ile varislerine devredilecekti ${ }^{47}$.

Doğu eyaletlerinin kötü durumu ve bu dönemde Suriye'ye yerleşmiş olan Misır kuvvetlerinin bölgeye sarkma ihtimali nedeniyle Osmanlı yetkilileri buraları bir an evvel kontrol altına almaya karar vermişlerdi. Ayrıca Padişah II. Mahmut'un reform hareketlerinin uygulamaya konması da böyle bir merkezîleşme hareketini zorunlu kılıyordu. Bu amaçla hem Misır tehdidini önlemek hem de bölgedeki beyleri kontrol altına almak için silahşorluğu ve cesaretiyle meşhur olan eski sadrazamlardan Reşit Mehmet Paşa 1833 y1lında Sivas Valiliği'ne atanmışt1 ${ }^{48}$.

Reşit Paşa 1833-1836 y1lları arasında Revanduzlu Mehmet Paşa'yı ortadan kaldırmış, Mardin'de patlak veren ciddi bir isyanı bastırmış, Milli aşireti önderliğindeki konfederasyonu dağıtmış, büyük Şamar Aşireti reisi Sufuk'u yakalayarak İstanbul'a göndermiş, Sincarlı Yezidileri ve Telaferli Türkmenleri cezalandırmış, Sason-Mafkan bölgesini kontrol altına almıştı ${ }^{49}$. $\mathrm{Bu}$ süreçte devlete kafa tutan beylerin imtiyazlarına da son vermişti. Örneğin kendisine direnen Cizre Beyi Mir Seyfettin üzerine yürümüş ve onu kaçmak zorunda bırakmıştı ${ }^{50}$. Bundan sonra da adamlarından birini Cizre'ye mütesellim olarak atamış ve bu şekilde Cizre Beyi bütün ayrıcalıklarını kaybetmişti ${ }^{51}$. Devlete itaat edenlerin ise mülklerine dokunmamıştı. Mesela

45 BOA, HAT, 490/24028-C, 3 Z.1250 (2 Nisan 1835).

46 BOA, HAT, 490/24028, 29 Z.1250 (1835); BOA, HAT, 490/24028-B, 29 Z.1250 (1835).

47 BOA, HAT, 490/24028-A, 29 Z.1250 (1835).

48 Takvim-i Vekayi, Defa 71.

49 Wadie Jwaideh, Kürt Milliyetçiliğinin Tarihi Kökenleri ve Gelişimi, (Çev. İsmail ÇekemAlper Duman) İletişim Yayınları, İstanbul 1999, s.105.

50 BOA, HAT, 448/22335-A, 3 N. 1254 (20 Kasim 1838).

51 BOA, İ.MSM 48/1225-13, 21 Za.1257 (4 Ocak 1842). 
Çarsancak Kazası'nın Karaçor nahiyesinde İsmail'in elinde bulunan yirmi kadar köye el konulmuş, İsmail Bey buraların kendisinin yurtluk ve ocaklığı olduğunu ispat edince topraklar kendisine iade edilmişti ${ }^{52}$. Ancak kardeş ve çocuğu olmayıp da ölen yurtluk-ocaklık sahiplerinin arazilerine el konularak Mansure Hazinesi devredilmişti ${ }^{53}$.

Reşit Paşa'nın ölümünden sonra Sivas Valiliği'ne Hafız Paşa atanmıştı. O da Reşit Paşa gibi Malatya'dan Telafer ve Musul'a kadar bölgelere seferler düzenlemişti. Ancak gerek Reşit Paşa ve gerekse Hafız Paşa dönemindeki faaliyetlerin tamamı Misır tehdidini önlemeye yönelikti. Bu nedenle bölgede kalıcı reformlar yapılmamıştı. Zaten Nizip Savaşı sonrası bölgedeki merkezîleşme faaliyetleri son bulmuş ve doğu eyaletleri 1839'dan 1847'ye kadar kaosa sürüklenmişti.

Bölgedeki merkezîleşme çabalarının ikinci aşaması Erzurum ve Diyarbakır Eyaletlerinin Tanzimat'a dahil edilmesiyle başlamıştı. Bilindiği gibi Tanzimat'ın uygulanmasına öncelikle merkeze yakın eyaletlerde başlanmıştı. Erzurum ve Diyarbakır eyaletlerinde ise 1845 Mart'ından itibaren uygulanmasına karar verilmişti. Buralarda devletin ilk amacı bir bakıma iktidar ortakları olan Kürt beylerini bölgeden uzaklaştırmaktı. Her iki eyalette de çok sayıda yerel bey ve sahip oldukları yurtluk-ocaklıklar bulunmaktaydı. Mesela sadece Muş'un dört yüzden fazla köyü yurtluk ve ocaklık hükmünde idii ${ }^{54}$ Güçlü beylerden, ağalara ve önde gelenlere kadar çok sayıda kişi bunların mutasarrıfları arasında yerlerini almıştı. Bu tarz topraklar ahalinin ezilmesinin sebeplerinden biri olduğu gibi aynı zamanda devlete başkaldıran beylerin temel güç kaynaklarını teşkil etmekteydi ${ }^{55}$. Bu nedenle Tanzimat'ın uygulanmasına karar verildiğinde Diyarbakır ve Erzurum Eyaletlerinde bulunan yurtluk-ocaklıkların feshedilmesi için hazırlıklar yapılmış, Tanzimat'ın ilanından sonra da bu bölgedeki vali ve defterdarlara bu konuda talimat verilmişti ${ }^{56}$. Buradaki temel amaç, toprağın asıl sahibi olan devletin denetimine geçmesini sağlamaktı. Ancak yaşadıkları bölgelerin Tanzimat'a dâhil edilmesi söz konusu beyleri hiç memnun etmemişti. Çünkü bunlar tüm ayrıcalıklarını kaybedeceklerinden korkuyorlardı. Ayrıca devletin buraları her türlü emri kayıtsız şartsız yerine getirecek memurlar vasitasıyla yönetmek istediğini biliyorlardı. Yani devletin nazarında bu gibi beylerin varlığı artık gereksizdi.

52 BOA, A.MKT, 29/3-3, 1261 (1845).

53 BOA, İ.MVL, 199/6225-2, 27 Ca.1266 (10 Nisan 1850).

54 BOA, HAT, 381/20579-A, 29. Z.1254 (1838).

55 BOA, A.MKT, 230/26, 29 Za.1265 (16 Ekim 1849).

56 BOA, MAD d., Nr. 7698, s.10-11. 
Tanzimat reformlarının hayata geçirilmesi sürecinde menfaat kaybına uğrayacak olan nüfuzlu kimseler Tanzimat'in ilan edildiği her yerde reformlara karşı çıkmışlardı. Halkı kışkırtarak Tanzimat'ın başarısız olması için ellerinden gelen her şeyi yapmışlard1 ${ }^{57}$. Erzurum bölgesinde ise özellikle yurtluk-ocaklık mutasarrıfları, tımar sahipleri ve diğer önde gelen Müslüman ahali Tanzimat'ın uygulanmasını istememişlerdi ${ }^{58}$. Gösterilen tepkiler Van Sancağı'nda şiddetli bir isyana dönüşmüştü. Van esnaf ve çiftçisinin büyük çoğunluğu Ermenilerden oluşuyordu. Müslümanlara gelince bunların bir kısmı tımar ve zeamet sahibi iken, önemli bir kısmı da yerli paşalara, beylere ve önde gelenlere hizmet ile geçiniyorlardı. Hıristiyanların kazançlarının büyük bölümü de bir şekilde beyler ve paşazadeler gibi önde gelenlerin eline geçmekteydi ${ }^{59}$. Eğer Tanzimat gerçek anlamıyla uygulanıp tımar, yurtlukocaklık sistemi düzene konulup, Hıristiyanların mal ve canları garanti altına alınırsa önde gelenler, toplumsal statüleri ile birlikte bütün ayrıcalıklarını kaybedeceklerdi.

Van isyanın arkasında Cizre Mütesellimi Bedirhan Bey, Müküs Sancağı Beyi Han Mahmut ve Hakkari Beyi Nurullah bulunmaktaydı. Bunlar Vanlıları ve bölgedeki aşiretleri kışkırtarak isyan ettirmiş̧lerdi. Böylece Tanzimat uygulamalarını öğrenmek için Erzurum'a talimat almaya giden Kaymakam Sırrı Paşa'nın geri dönüşünde Van'a girmesine engel olmuşlardı. Erzurum Valisi Bekir Sami Paşa'nın tüm girişimlerine rağmen bunlarla uzlaşılamamışt1 ${ }^{60}$.

1845 Temmuz'unda Kars ve Çıldır'dan gelen haberler Tanzimat'a karşı hoşnutsuzluğun giderek yayıldığını gösteriyordu. Her biri bulundukları kazalarda yurtluk-ocaklık sahibi olan Posof Beyi Kamil, Tavasger Beyi Dursun, Ardahan Beyi Hasan, Göle Beyi Arslan, Mirho Beyleri Osman ve Hüseyin, Ahmetpaşazade Şerif Bey, Livaneli Yusuf Bey ve Abdi Bey bir araya gelerek Tanzimat'a karşı direnmeye karar vermişlerdi ${ }^{61}$. Bunların Tanzimat'ın uygulanmasını engellemek için kuvvetlerini toplayarak hep birlikte Erzurum üzerine yürüyecekleri haber verilmişti ${ }^{62}$. Bekir Sami Paşa gerginliği ortadan kaldırmak için yurtluk-ocaklıklara dokunulmayacağına

57 Ahmet Uzun, Tanzimat ve Sosyal Direnişler Niş İsyanı Üzerine Ayrıntılı Bir Inceleme (1841), Eren Yayınları, İstanbul 2002, s.11.

58 Musa Çadırcı, Tanzimat Döneminde Anadolu Kentleri'nin Sosyal ve Ekonomik Yapısı, TTK, Ankara 1997, s.193.

59 Mehmed Hurşid Paşa, a.g.e., s. 237.

${ }^{60}$ BOA, İ.MSM, 49/1234-1, 9 L. 1261 (11 Eylül 1845).

61 BOA, İ.MSM, 49/1232-13, 19 B.1261 (24 Temmuz 1845).

62 BOA, MVL, 3/20-14, 11 N.1261 (13 Eylül 1845). 
dair bunlara haber göndermek zorunda kalmıştı. Bu sırada Van'a asker sevk edilmesi düşünülmekteydi. Bu amaçla da Ferik Bahri Paşa Eleşkirt'te bulunmaktaydı. Ancak Çıldır bölgesinin de karışması yetkilileri endişelendirmişti. Çünkü iki tarafa birden müdahale için yeterli sayıda asker bulunmamaktayd $1^{63}$.

Bölgedeki karışıklıklar mali sıkıntıları da beraberinde getirmişti. 1845 Mart'ından beri Çıldır ve Van'dan bir akçe vergi toplanamadığından Erzurum Eyaleti'nin gelirleri masraflarını karşılamaya yetmemişti ${ }^{64}$. Bu nedenle maaş alamayan askerler arasında da hoşnutsuzluk giderek artmıştı. Ama hükümet ne olursa olsun Tanzimat'1 uygulamaktan vazgeçmek niyetinde değildi. Çünkü bu konuda atılacak bir geri adım ya da kararsızlık Diyarbakır Eyaleti'nde de benzer sorunların ortaya çıkmasına sebep olabilirdi ${ }^{65}$.

Çıldır ve Acara bölgesindeki muhalifler ile Vanlı asilerin birleşme ihtimali Osmanlı yönetimini oldukça endişelendirmişti. Gelen bilgilere göre Çıldır civarında nüfuz sahibi olan Kör Hüseyin Bey, Bedirhan Bey ve Vanlılarla işbirliği yapmaya çalışmaktayd ${ }^{66}$. Ancak bu hoşnutsuzlukları birleştirip devlete karşı toplu bir şekilde tepkileri ortaya koyacak yeteneğe sahip birisinin olmaması yetkilileri rahatlatmıştı.

Anlaşıldığ 1 kadarıyla yurtluk-ocaklıklara el konulmayacağına dair haberlerin Çıldır'a ulaşması bölgenin sakinleşmesini sağlamıştı ${ }^{67}$. Çıldır meclisinin bir yazısında ifade edildiğine göre yurtluk-ocaklık, malikâne ve tımar arazilerinin Tanzimat usulünce hasılatının bilinmesi amacıyla bu senelik devlet tarafindan işletileceği aşarı alındıktan sonra hasılatının sahiplerine iade edileceği halka iyi bir şekilde anlatılmıştı. Böylece beyler yaptıklarından pişman olmuşlar ve Çıldır'da durum sakinleşmişti ${ }^{68}$.

Ancak Van isyanı tüm çabalara rağmen hala devam etmekteydi. Üstelik bu süreçte Bedirhan Bey, Han Mahmut ve Nurullah Bey 1846 y1lında ikinci kez Hakkâri'deki Nasturiler üzerine saldırarak büyük bir katliam ve yağma hareketine girişmişlerdi. Bunun üzerine Osmanlı merkezî yönetimi ne pahasına olursa olsun başta Bedirhan Bey olmak üzere bu beyleri ortadan kaldırmayı karar vermişti. Bunun için 1846 yılında hazırlıklara başlanmış ve 1847 baharında Anadolu Ordusu Müşiri Osman Paşa kumandasındaki

63 BOA, İ.MSM, 49/1232-14, 21 B.1261(26 Temmuz 1845).

64 BAO, İ.MSM, 49/1232-15, 1 Ş.1261 (5 Ağustos 1845).

65 BOA, C.DH, 45/2208, 28 L.1261(30 Ekim 1845).

66 BOA,A.MKT, 249/33, 29 R.1262 (26 Nisan 1846).

67 BOA, İ.MSM, 49/1233-2, 25 Ş.1261 (29 Ağustos 1845).

68 BOA, İ.MSM, 49/1233-1, 1261 (1845). 
Osmanlı birlikleri Cizre üzerine yürümüştü. Meydana gelen birkaç çatışmadan sonra Cizre Mütesellimi Bedirhan Bey 1847 Temmuz'unda yakalanmıştı. Aynı ay içerisinde Van üzerine yürüyen Osmanlı birlikleri Han Mahmut'u yakalayarak Van isyanına son vermişlerdi ${ }^{69}$.

Bedirhan ile diğer beylerin ve Vanlıların isyanı yaklaşık üç yıla yakın sürmüştü. Osmanlı hükümeti bu isyanı bastırdıktan sonra Erzurum ve Diyarbakır Eyaletlerinde Tanzimat'ı uygulamaya geçirebilmişti. Bölgede asayiş sağlandıktan hemen sonra Diyarbakır Eyaleti ile Van, Muş, Hakkâri sancakları ve Cizre, Bohtan, Mardin kazaları birleştirilerek Aralık 1847'de Kürdistan Eyaleti kurulmuştu ${ }^{70}$. Bundan sonra Kürt beylerinin kaymakam olmalarının yolu kapanmıştı ${ }^{71}$. Bu nedenle bölgeden uzaklaştııılmayan beylerin bulundukları sancaklar olan aynı zamanda yurtluk-ocaklık statüsünde bulunan Muş ve Hakkâri bir süreliğine müdürlükle idare edilmişti.

1848 yllında ise bu kez eski Hakkâri Beyi yeni Hâkkari Müdürü Nurullah Bey ve Müküs Kazası Müdürü Abdal Bey isyan etmişti. Bu beyler de Osmanlı yetkililerini epey uğraştırmışsa da yaklaşık bir buçuk yıl sonra her iki isyan da bastırılmıştı ${ }^{72}$.

Böylece 1833 y1lında başlayan merkezîleşme hareketlerinin önündeki en büyük engeller olan beylerin bölgeden uzaklaştırılma süreci 1849 yılında tamamlanmıştı. Yukarıda ifade edildiği gibi Tanzimat ilan edildikten hemen sonra devlet, yurtluk-ocaklıklara el koymayı planlamış ancak Bedirhan Bey isyanı ve sonra ortaya çıkan Nurullah Bey meselesi bu planın bir süreliğine ertelenmesine neden olmuştu. Yurtluk-ocaklıkların düzenlenmesi önündeki bütün engeller Nurullah Bey'in ele geçirilmesiyle ortadan kalkmış ve ilk önce Nurullah Bey'in yirmi beş kadar köyüne el konularak söz konusu plan uygulanmaya konmuştu ${ }^{73}$. Daha sonra Hakkâri ümerâsının tasarrufunda bulunan köylere el konularak, buralar 50905,5 kuruşa ihale edilmiş ve bu meblağ yurtluk-ocaklıklarına karşılık mutasarrıflarına maaş olarak bağlanmıştı ${ }^{74}$. Maaş bağlanan kişiler aşağıdaki tabloda gösterilmiştir: ${ }^{75}$

69 Fatih Gencer, Merkezîyetçi İdari Düzenlemeler Bağlamında Bedirhan Bey Olayı, Basılmamış Doktora Tezi, Ankara Üniversitesi Sosyal Bilimler Enstitüsü, Ankara 2010, s.195-196.

70 BOA, A.MKT, 103/64, 27.Z.1263 (6 Aralık 1847).

${ }^{71}$ BOA, İ.MSM, 52/1346-1, 9 L.1264 (8 Eylül 1848).

72 Fatih Gencer, a.g.e., s.229-237.

73 BOA, A.MKT.DV, 176/22, 11 Ca.1277, (25 Kasim 1860).

74 BOA, İ.MVL, 284/11195-2, 15 Z.1269 (19 Eylül 1853).

75 BOA, ML.VRD, Nr. 1778, 3 Za 1269 (8 Ağustos 1853). 


\begin{tabular}{|c|c|c|}
\hline Maaş Alan & $\begin{array}{c}\text { Yıllık Geliri } \\
\text { (kuruş) }\end{array}$ & Aylık Maaşı \\
\hline Şeyh Seyyid Mehmet bin Abdurrahman & 1150 & 95 kuruş 30 para \\
\hline Muhyiddin Efendi & 1785 & 148 kuruş 30 para \\
\hline Şeyh Nureddin Efendi & 1839 & 153 kuruş 30 para \\
\hline Mustafa Beyzade Abdullah Bey & 1623 & 135 kuruş 35 para \\
\hline Timurbeyzade Yusuf Bey & 3410 & 284 kuruş 20 para \\
\hline Mahmut Efendizade Abdülkadir Efendi & 567 & 47 kuruş 40 para \\
\hline Mustafa Ağa & 1572 & 131 \\
\hline Mahmut Ağazade Halil Ağa & 1525 & 127 kuruş 10 para \\
\hline Mustafa Ağazade Şerif A ̆ga & 1652 & 137 \\
\hline Abdülaziz A Agazade Mehmet Ağa & 1861 & 155 kuruş 15 para \\
\hline Abdullah Ağazade Hüseyin Ağa & 903 & 75 kuruş 35 para \\
\hline Sero Beyzade İshak Bey & 2850 & 287 kuruş \\
\hline Molla Halil oğlu Molla İbrahim & 325 & 27 kuruş 10 para \\
\hline $\begin{array}{c}\text { Molla Abdullah ve kardeşi Molla Sadullah } \\
\text { Molla Abdullah hissesi } \\
\text { Molla Sadullah hissesi }\end{array}$ & 325 & $\begin{array}{l}27 \text { kuruş } 10 \text { para } \\
13 \text { kuruş } 5 \text { para } \\
13 \text { kuruş } 5 \text { para }\end{array}$ \\
\hline Şeyh Mahmud Efendi & 450 & 37 kuruş \\
\hline $\begin{array}{c}\text { Abdurrahman ve Timur Beyler } \\
\text { Abdurrahman Bey'in hissesi } \\
\text { Timur Bey'in hissesi }\end{array}$ & 635 & $\begin{array}{l}52 \text { kuruş } 50 \text { para } \\
26 \text { kuruş } 55 \text { para } \\
26 \text { kuruş } 55 \text { para }\end{array}$ \\
\hline Bekir Ağazade Abdurrahman Ağa & 225 & 18 kuruş 30 para \\
\hline Mehmet Ağazade Ahmet Ăga & 1200 & 100 kuruş \\
\hline Abdullah Beyzade Gülali Bey & 175 & 14 kuruş 10 para \\
\hline $\begin{array}{c}\text { Abdülhamit, Molla Hacı ve Hasan beylerin } \\
\text { Abdülhamit'in hissesi } \\
\text { Molla Hacı'nın hissesi } \\
\text { Hasan'ın hissesi }\end{array}$ & 750 & $\begin{array}{c}62 \text { kuruş } \\
20 \text { kuruş } 40 \text { para } \\
20 \text { kuruş } 40 \text { para } \\
20 \text { kuruş } 40 \text { para }\end{array}$ \\
\hline Mahmut Beyzade Sado & 450 & Aylık 37 kuruş \\
\hline Mehmet Ağazade Keleş Ağa & 225 & 18 kuruş 30 para \\
\hline Abdülganizade Abdülhamit & 200 & 16 kuruş 20 para \\
\hline $\begin{array}{c}\text { Ali Nebati ve Şahin Beylerin } \\
\text { Ali Nebati'nin hissesi } \\
\text { Şahin'in hissesi } \\
\end{array}$ & 270 & $\begin{array}{l}22 \text { kuruş } \\
11 \text { kuruş } 10 \text { para } \\
11 \text { kuruş } 10 \text { para } \\
\end{array}$ \\
\hline $\begin{array}{c}\text { Şemdin bin Mehmet ve Hasan bin Yusuf } \\
\text { Şemdin bin mehmet'in hissesi } \\
\text { Hasan bin Yusuf'un hissesi }\end{array}$ & 150 & $\begin{array}{c}12 \text { kuruş } \\
6 \text { kuruş } 10 \text { para } \\
6 \text { kuruş } 10 \text { para } \\
\end{array}$ \\
\hline Keleş bin Abdurrahman & 450 & 37 kuruş \\
\hline $\begin{array}{l}\text { Serkar ve Bayezid Ağaların } \\
\text { Serkar Ağanın hissesi } \\
\text { Bayezid Ağanın hissesi } \\
\end{array}$ & 285 & $\begin{array}{l}23 \text { kuruş } 30 \text { para } \\
11 \text { kuruş } 10 \text { para } \\
11 \text { kuruş } 10 \text { para } \\
\end{array}$ \\
\hline Abdal bin Abdülhalil & 430 & 25 kuruş 40 para \\
\hline Şakir Ağazade Mehmet Ağa & 710 & 59 kuruş 20 para \\
\hline
\end{tabular}




\begin{tabular}{|c|c|c|}
\hline $\begin{array}{c}\text { Ömer Nebati ve Behram?'ın } \\
\text { Ömer Nebati'nin hissesi } \\
\text { Behram'ın hissesi }\end{array}$ & 250 & $\begin{array}{l}20 \text { kuruş } 40 \text { para } \\
10 \text { kuruş } 50 \text { para } \\
10 \text { kuruş } 50 \text { para } \\
\end{array}$ \\
\hline Hüseyin bin Ömer & 750 & 62 kuruş \\
\hline $\begin{array}{l}\text { Musa ve Timur Beylerin } \\
\text { Musa Bey'in hissesi } \\
\text { Timur Bey'in hissesi } \\
\end{array}$ & 810 & $\begin{array}{c}67 \text { kuruş } \\
33 \text { kuruş } 10 \text { para } \\
33 \text { kuruş } 10 \text { para } \\
\end{array}$ \\
\hline Hüseyin bin Hakk1 & 800 & 66 kuruş 20 para \\
\hline $\begin{array}{c}\text { Memo veled-i Aro ve Katal? veled-i Ebuzid? } \\
\text { Aro'nun hisesi } \\
\text { Ebuzid'in hissesi }\end{array}$ & 200 & $\begin{array}{l}16 \text { kuruş } 20 \text { para } \\
8 \text { para } 40 \text { kuruş } \\
8 \text { para } 40 \text { kuruş } \\
\end{array}$ \\
\hline $\begin{array}{c}\text { Hasan Ağa bin Halid ve Mehmet bin Seyyid } \\
\text { Hasan Ağa'nın hissesi } \\
\text { Mehmet Ağa'nın hissesi }\end{array}$ & 520 & $\begin{array}{c}43 \text { kuruş } \\
21 \text { kuruş } 20 \text { para } \\
21 \text { kuruş } 20 \text { para }\end{array}$ \\
\hline $\begin{array}{c}\text { Ahmet bin Mustafa ve Piri bin Mola Zekeriyya } \\
\text { Piri'nin hissesi } \\
\text { Ahmet'in hissesi }\end{array}$ & 550 & $\begin{array}{l}45 \text { kuruş } 40 \text { para } \\
22 \text { kuruş } 50 \text { para } \\
22 \text { kuruş } 50 \text { para }\end{array}$ \\
\hline Memo bin Hacı Abdullah & 140 & 11 kuruş 20 para \\
\hline Osman Beyzade Abdülhamit Bey & 1065 & 88 kuruş 30 para \\
\hline Musa Bey & 2150 & 189 kuruş 20 para \\
\hline Rustem Bey & 1851 & 154 kuruş 30 para \\
\hline $\begin{array}{l}\text { Yesr? Ve Mir Nebati Abdullah } \\
\text { Yesr Ağa'nın hissesi } \\
\text { Mir Nebati Abdullah'ın hissesi } \\
\end{array}$ & 450 & $\begin{array}{l}37 \text { kuruş } 50 \text { para } \\
18 \text { kuruş } 10 \text { para } \\
18 \text { kuruş } 10 \text { para } \\
\end{array}$ \\
\hline Han İran bin Hasan & 1400 & 112 kuruş 20 para \\
\hline Ali Ağazade Mirza Ağa & 4025 & 335 kuruş 50 para \\
\hline Keleş bin Keleş & 600 & 50 kuruş \\
\hline Hazarbeyzade Ahmet & 750 & 26 kuruş \\
\hline Evliya bin Abdurrahman & 350 & 29 kuruş 20 para \\
\hline Abdullah Ağazade Kazım Ağa & 550 & 45 kuruş 40 para \\
\hline Mirza bin Mehmet & 400 & 33 kuruş 40 para \\
\hline Ömer Ağazade Nezir Ağa & 1100 & 91 kuruş 20 para \\
\hline $\begin{array}{c}\text { Ömer Ağa, Osman Ağa ve Abdülaziz Ağa } \\
\text { Ömer Ağa'nın hissesi } \\
\text { Osman A ̆ga'nın hissesi } \\
\text { Abdülaziz Ağa'nın hissesi }\end{array}$ & 250 & $\begin{array}{l}20 \text { kuruş } 40 \text { para } \\
6 \text { kuruş } 53 \text { para } \\
6 \text { kuruş } 53 \text { para } \\
6 \text { kuruş } 53 \text { para } \\
\end{array}$ \\
\hline Kel Mehmet bin Abdullah & 700 & 57 kuruş 40 para \\
\hline Sero Ağazade Gelhun? & 400 & 33 kuruş 40 para \\
\hline Abdurrahman Ağazade Keleş Ağa & 200 & 16 kuruş 20 para \\
\hline Abdüllatif Ağazade Abdi Bey & 600 & 50 kuruş \\
\hline Çölemerik kazası sakini Bekir & 1000 & 83 kuruş 40 para \\
\hline Şakir Ağazade Mehmet Ağa & 250 & 20 kuruş 40 para \\
\hline Molla Mehmet Abdülbaki & 275 & 22 kuruş 50 para \\
\hline Toplam & 50.905 & 4.242 kuruş 15 para \\
\hline
\end{tabular}


Nurullah Bey yakalandıktan sonra her ne kadar isyan etmemiş olsalar da yetkililer Muşlu Şerif Bey ve kardeşlerinin de aileleriyle birlikte İstanbul'a gönderilmesine karar vermişlerdi ${ }^{76}$. Daha sonra da Şerif Bey'in isteği üzerine İstanbul'dan vazgeçilerek onun ailesiyle birlikte Şam'da yaşamasına müsaade edilmişti ${ }^{77}$. Bunların arazilerine el konulduktan sonra 1265 (1848) senesi gelirlerinin 52.298,5 kuruş olduğu hesaplanmıştı. Ancak bunlara uygun bir maaş bağlanması için 1266 (1849) senesi gelirinin de belirlenmesi istenmişti. Bu amaçla yapılan tahkikata göre 1266 y1lı Şerif Bey ve kardeşlerinin köylerinin hasılatı aşağıdaki şekilde hesaplanmışt ${ }^{78}$ :

$\begin{array}{lr}\text { Şerif Bey'in üzerindeki köylerin hasılatı } & 43.145 \\ \text { Kardeşi Murat Beyin köylerinin hasılatı } & 25.870 \\ \text { Diğer kardeşi Hurşit Bey'in köylerinin hasılatı } & 31.010 \\ & +------- \\ & 100.025\end{array}$

İki sene hasılatının arasında bu kadar fark olması nedeniyle iki senelik gelirin ortalaması alınıp masrafları çıkarıldıktan sonra kalan miktarın maaş olarak bağlanmasına karar verilmişti ${ }^{79}$. Bu işlem sonucu bağlanacak yıllık maaşın toplamı masraflar dâhil 76.161,75 kuruş olmuştu. Elimizdeki bir belge Şerif Bey'in kardeşleri Murat ve Hurşit Beylere aylık 2000 kuruş maaş bağlandığını göstermektedir ${ }^{80}$. Bu durumda Şerif Bey'e de 2000 kuruş maaş bağlandığ 1 söylenebilir. Üç kardeşin maaşının toplamı senelik 72000 kuruş yapmaktadır. Demek ki 4165,75 kuruş masraf olarak kesilmiş, kalanı da bunlara maaş olarak bağlanmıştı.

Anlaşıldığ 1 kadarıyla yurtluk-ocaklık sahiplerine bağlanan maaşın hesaplanmasında belirli bir sistem izlenmiyor, duruma göre hareket ediliyordu. Mesela Hizan Kazası'nın yüz kadar köyü yurtluk-ocaklık olarak Şerefettin Bey'in tasarrufundaydı. Bu köyler devlet tarafindan zapt edilmiş ve 121.000 kuruşa ihale edilmişti. Karşıllğında 1849 Haziran'ında itibaren Şerefettin Bey'e 2.000, kardeşleri Derviş ve Nurullah beylere 500'er kuruş maaş bağlanmışt ${ }^{81}$. Böylece bu köylerden elde edilen y1llık gelirin 36.000 kuruşu yani yaklaşık üçte biri maaş olarak ödendikten sonra geri kalan

76 BOA, İ.DH, 193/10876-6, 3 Ca.1265 (27 Mart 1849).

77 BOA, A.MKT, 225/82, 3 Za.1265 (20 Eylül 1849); BOA, İ.DH, 197/11181, 10 Ş.1265 (1 Temmuz 1849); BOA, İ.DH, 202/11557, 20 Za.1265 (7 Ekim 1849).

78 BOA, İ.MVL 198/6184-1, 1267(1850)

79 BOA, İ.MVL 198/6184-10, 27 Ra.1267 (30 Ocak 1851); BOA, A.AMD 29/16, 23 Ra. 1267 (26 Ocak 1851)

80 BOA, MADd., Nr, 7910 s.1.

81 BOA, A.DVN, 58/89, 27 Ca.1266 (10 Nisan 1850). 
85.000 kuruşun doğrundan devlet hazinesine gitmesinin yolu açılmıştı. Bu miktar 1849 senesi Kürdistan Eyaleti'nin gelir artışı arasında yerini almıştı ${ }^{82}$.

Benzer işlem Erzurum Eyaleti'ne bağlı bölgelerde de uygulanmıştı. Mesela Çıldır Sancağında bulunan otuz beş kişinin yurtluk-ocaklık statüsündeki köylerine 1268 (1851) tarihinden itibaren el konulmuştu. Buraların senelik hasılatının 126800 kuruş olduğu hesaplanmış ve sahiplerine aylık toplam 10567,5 maaş bağlanmışt1 ${ }^{83}$. Ancak yurtlukocaklıkların belirli bir kaydı bulunmadığından el konulma işlemi yaklaşık on beş yıla yakın bir süreçte tamamlanmış ve bu süre zarfinda el konulan yurtluk-ocaklık sayısı sürekli artmıştı. Örneğin 1851 tarihinde Çıldır'da bağlanan maaş 126800 kuruşken, bu miktar 1884 yılında 273000 kuruşa kadar yükselmişti. Aşağıdaki tablo 1884 yılında Çıldır Sancağı'nca verilen yurtluk-ocaklık maaşlarını göstermektedir: ${ }^{84}$

\begin{tabular}{|c|c|}
\hline Maaş Alan & Aylık maaşı \\
\hline Çıldır Hanedanından Hüseyin Bey & 76 Kuruş 9 Para \\
\hline Mehmet Bey & 76 Kuruş 9 Para \\
\hline Süleyman Bey & 76 Kuruş 9 Para \\
\hline Müteveffa Osman Mahdumu Ali Seyfettin Bey & 114 Kuruş 43 Para \\
\hline Diğer Mahdumu Süleyman Bey & 114 Kuruş 43 Para \\
\hline Mehmet İzzet Bey & 281 Kuruş 45 Para \\
\hline Arslan Bey & 281 Kuruş 45 Para \\
\hline Süleyman Bey & 281 Kuruş 45 Para \\
\hline Hasan Bey & 78 Kuruş 15 Para \\
\hline Hüseyin Bey & 78 Kuruş 15 Para \\
\hline Derviş Hamza Bey & 78 Kuruş 15 Para \\
\hline Tahir Bey & 1280 Kuruş 15 Para \\
\hline Selim Dede Bey & 610 Kuruş 13 Para \\
\hline Ahmet Şakir Bey & 610 Kuruş 13 Para \\
\hline Salih Bey & 68 Kuruş 45 Para \\
\hline Galip Bey & 68 Kuruş 42 Para \\
\hline Hasan Bey & 68 Kuruş 42 Para \\
\hline Osman Bey & 68 Kuruş 42 Para \\
\hline Süleyman Bey & 68 Kuruş 42 Para \\
\hline Yusuf Tayyar Efendi & 68 Kuruş 42 Para \\
\hline Mehmet Bey & 68 Kuruş 42 Para \\
\hline Süleyman Bey & 68 Kuruş 42 Para \\
\hline Ali Bey & 68 Kuruş 42 Para \\
\hline
\end{tabular}

BOA, İ.MVL, 188/5680-94, 1265 (1849).

33 BOA, İ.MVL, 303/12420-2, 19 N. 1270 (15 Haziran 1854).

84 BOA, MAD d., Nr.,7910 s.2. 


\begin{tabular}{|c|c|}
\hline Mehmet Atıf Bey & 1061 Kuruş 49 Para \\
\hline Mehmet Abdurrahman Bey & 1061 Kuruş 49 Para \\
\hline Mehmet Şakir Bey & 1042 Kuruş \\
\hline Mehmet Sadik Bey & 1042 Kuruş \\
\hline Murtaza Bey & 26 Kuruş 37 Para \\
\hline Mehmet Tosun Bey & 26 Kuruş 37 Para \\
\hline Meded Mustafa Bey & 26 Kuruş 37 Para \\
\hline Hamza Yasin Bey & 26 Kuruş 37 Para \\
\hline Süleyman Sani Bey & 26 Kuruş 37 Para \\
\hline Yusuf Tayyar Bey & 26 Kuruş 37 Para \\
\hline Ali Turuk? Bey & 457 Kuruş 5 Para \\
\hline Çıldır Ahalisinden Hüseyin Bey & 488 Kuruş 6 Para $(9969,25)$ \\
\hline Süleyman Bey & 488 Kuruş 6 Para \\
\hline Mehmet Sefer Bey & 488 Kuruş 6 Para \\
\hline Acara Ahalisinden Süleyman Bey & 790 Kuruş 25 Para \\
\hline Acara Ahalisinden Ali Seyfettin Bey & 790 Kuruş 25 Para \\
\hline Arslan Ali Bey & 446 Kuruş 48 Para \\
\hline İzzet Bey & 446 Kuruş 48 Para \\
\hline Süleyman Kâmil Bey & 446 Kuruş 48 Para \\
\hline Mehmet Dursun Bey & 921 Kuruş 30 Para \\
\hline Süleyman Sani Bey & 552 Kuruş \\
\hline Süleyman Bey & 41 Kuruş 38 Para \\
\hline Hüseyin Bey & 41 Kuruş 38 Para \\
\hline Mehmet Bey & 41 Kuruş 38 Para \\
\hline Müteveffa Abdullah Bey mahdumu Mehmet Şerif Bey & 233 Kuruş 12 Para \\
\hline Yusuf Tayyar Bey & 552 Kuruş 15 Para \\
\hline Ahmet Beyzade Süleyman Bey & 50 Kuruş 30 Para \\
\hline Mehmet Şerif Beyzade Meded Mustafa Bey & 206 Kuruş 27 Para \\
\hline Hamza Yasin Bey & 206 Kuruş 27 Para \\
\hline Hasan Bey & 1741 Kuruş 45 Para \\
\hline Hüseyin Bey & 1741 Kuruş 45 Para \\
\hline Derviş Hamza Bey & 1741 Kuruş 45 Para \\
\hline Mehmet Salih Bey & 12 Kuruş 7 Para \\
\hline Mehmet Galip Bey & 12 Kuruş 7 Para \\
\hline Hasan Bey & 12 Kuruş 7 Para \\
\hline Osman Bey & 12 Kuruş 7 Para \\
\hline Hasan Bey & 250 Kuruş 30 Para \\
\hline Hüseyin Bey & 250 Kuruş 30 Para \\
\hline Derviş Hamza Bey & 250 Kuruş 30 Para \\
\hline Toplam $^{85}$ & 22754 Kuruş 14 Para \\
\hline
\end{tabular}

85 Toplamı yanlış verilmiş. Eğer biz de yanlış toplamadıysak doğrusunun 22237 Kuruş 79 Para olması gerekir. 
El konulan yurtluk-ocaklıklara karşılık tahsis edilen maaşların miras bırakılmasına müsaade edilmişti ${ }^{86}$. Başlangıçta sadece erkek çocuklar bu maaşlardan faydalanmışlardı. Daha sonra Arazi Kanunnâmesi'nin yürürlüğe girmesiyle birlikte kız çocuklar da varis olarak kabul edilmiş ve onlara da maaş bağlanmıştı ${ }^{87}$.

Aşağıdaki tablo eski Bayezid Kaymakamı Behlül Paşa'nın varislerine bağlanan maaşlar da gösterilmektedir: ${ }^{88}$

\begin{tabular}{|l|c|}
\hline Mehmet Bey & 642 Kuruş 14 Para \\
\hline Mahmut Bey & 642 Kuruş 14 Para \\
\hline Abdülhamit Bey & 642 Kuruş 14 Para \\
\hline İbrahim Bey & 642 Kuruş 14 Para \\
\hline İzzet Bey & 642 Kuruş 14 Para \\
\hline Şerife Hanım & 642 Kuruş 14 Para \\
\hline Badisaba Hanım & 642 Kuruş 14 Para \\
\hline Toplam & 4494 Kuruş 98 Para \\
\hline
\end{tabular}

Tabloya bakıldığında Arazi Kanunnâmesi'nin ilgili hükümleri gereği kadınların da erkekler gibi yurtluk-ocaklık maaşından faydalandığ 1 görülmektedir. Ayrıca aylık toplam 4495, 98 kuruş maaş göz önüne alınırsa, Behlül Paşa'ya yurtluk-ocaklıklarına karşılık bağlanan maaşın yıllık toplamının 53.940 kuruş olduğu söylenebilir.

Yukarıdaki bilgiler ışığında Çıldır, Hakkâri, Muş, Hizan ve Bayezid sancaklarındaki belli başlı kişilere bağlanan maaşlar toplamının beş yüz bin kuruşu aştığ görülmektedir. Şüphesiz bu sancaklarda bu beyler dışında çok sayıda kiși yurtluk-ocaklık sahibiydi. Nitekim buna dair elimizde bazı bilgiler mevcuttur ${ }^{89}$. Elimizde diğer bölgelerle, özellikle Van, Diyarbakır,

${ }^{86}$ BOA, A.AMD, 85/63, 1276 (1859).

87 BOA, İ.ML, 1311.Z.29/24, 3 Temmuz 1894. 1858 tarihli Arazi Kanunnâmesi'nin intikal ile ilgili hükmü şöyledir: "Arazi-i mîriye ve mevkûfe mutasarrıf ve mutasarrifelerinden biri fevt oldukda uhdesinde olan arazi erkek ve kız evladina gerek arazinin olduğu mahalde bulunsunlar ve gerek diyâr-i âherde olsunlar meccanen ve bilâ-bedel mütesâviyyen intikal eyler yalnız erkek veyahud yalnız kız evladı olur ise kezalik bilâ-bedel müstakilen intikal ider...” Bkz. Düstur, Cilt 1, s. 186, 7 N. 1274 (21 Nisan 1858)

88 BOA, MAD d., Nr, 7910 s.1.

89 Mesela yukarıdaki listede yer almayan ancak başka bir belgede yurtluk-ocaklıklarına karşılık maaş bağlanan Hakkâri Beylerinden Müftizade Molla Taha adlı bir şahıstan bahsedilmektedir. Bkz. BOA, İ.MVL 336/17259-6, 14 Za.1274 (26 Haziran 1858). Ayrica bir diğer belgede de Seyfi ve Reşit Beylerin Muş'ta bulunan yurtluk-ocaklıklarına karşıllık maaş bağlandığı ifade edilmektedir. Bkz. BOA, İ.MVL, 316/13303-2, 22 M.1271 (15 Ekim 1854) 
Harput ile ilgili veriler olmasa da buraların da dâhil edilmesi durumunda yurtluk-ocaklık sistemine giden paranın milyonlarca kuruşa ulaştığını söyleyebiliriz. Böyle bir meblağın hiçbir iş yapmadıkları halde beylere ve önde gelenlere gittiği göz önüne alınırsa bu sistemin devletin sırtında nasıl bir kambur olduğu net olarak anlaşılabilir.

19. yüzyllın sonuna doğru devletin ekonomik durumunun giderek kötüleşmesi nedeniyle yurtluk-ocaklıklara karşılık ödenen maaşların yeniden düzenlenmesi gündeme gelmiş ve maaşların intikalini sınırlandıran 1894 tarihli bir öneri hazırlanmıştı. Buna göre maaşlar sadece evlada intikal edecek, çocuğu olmadan ölenlerin hakları hazineye devredilecekti. Ancak bu talebe sıcak bakılmamış, yurtluk-ocaklıklara karşılık ödenen maaşların aile efradına intikal etmesi tekrar karara bağlanmıştı ${ }^{90}$. Böylece yurtluk-ocaklık sistemi bu şekliyle imparatorluğun sonuna kadar varlığını sürdürmüştü.

Sonuç olarak şunu söyleyebiliriz ki Tanzimat'ın uygulanmasıyla birlikte güçlü beylerin büyük bir kısmı sürgün edilmiş, bunların ve sürgün edilmeyen diğer beylerin yurtluk ocaklıklarının tamamına maaş karşılığında el konulmuştu. Böylece dönemin en önemli güç kaynă̆ı olan toprak, asıl sahibi olan devletin denetimine geçirilmiş̧i. Yurtluk-ocaklık sisteminin doğrudan feshedilmesi yerine sahiplerine maaş bağlanmasının nedeni ise kanaatimizce sayıları binlere varan önde gelenlerin tepkisini bir anda çekmemekti. Devlet, bunlara maaş bağlayarak bir geçiş süreci yaratmaya çalışmıştı. Zaten bu maaşlar varislere intikal ede ede zamanla eriyip bitecekti. Maaş bağlanan kişiler çalışmaya alışmadıklarından ve ticareti de bilmediklerinden tamamen bu aylıklara bağımlı hale gelmişlerdi. Böylece modernleşme ve merkezîleşme politikalarına muhalefet edebilecek olan en önemli kesim etkisiz hale getirilmişti.

90 BOA, İ.ML, 1311.Z.29/24, 3 Temmuz 1894. 


\section{Kaynakça}

\section{Arşiv Belgeleri*}

Başbakanlık Osmanlı Arşivi

Sadaret Amedi Kalemi (A.AMD)

Sadaret Divan Kalemi (A.DVN)

Sadaret Mektubi Kalemi (A.MKT)

Sadaret Mektubi Kalemi Deavaî (A.MKT.DV)

Sadaret Mektubi Kalemi Nezaret ve Devâir (A.MKT. NZD)

Cevdet Dahiliye (C.DH)

Hatt1-1 Hümayun (HAT)

İrade Dahiliye (İ.DH)

İrade Maliye (İ.ML)

İrade Mesâil-i Mühimme (İ.MSM)

İade Meclis-i Vala (İ.MVL)

Maliyeden Müdevver (MAD.d)

Maliye Nezareti Varidat Defteri (ML.VRD.d.)

Meclis-i Vala Riyaset Belgeleri (MVL)

\section{Kaynak Eserler, Araştırma ve İncelemeler}

Ayn-1 Ali Efendi, Kavânîn-i Âl-i Osman der Hülâsa-i Mezâmin-i Defter-i Divan, (Haz. M. Tayyib Gökbilgin), Enderun Yayınları, İstanbul 1979.

AVERYANOF, P., 19. Asirda Rusya, Türkiye, Iran Muharebeleri Türk-Iran-Rus Kürtlerinin Vaziyet-i Hazıraları, (Çev. Yüzbaşı Mustafa Efendi-Mülazım Adil Efendi), Hâkimiyet-i Milliye Matbaası, Ankara 1926.

BRANT, James - GLASCOTT, A.G., "Notes of a Journey Through a Part of Kurdistán, in the Summer of 1838", Journal of the Royal Geographical Society of London, Vol. 10. (1840), s.341-434.

CUNNINGHAM A. B. (Ed.), The Early Correspondence Of Richard Wood (18311841), London 1966.

ÇADIRCI, Musa, Tanzimat Döneminde Anadolu Kentleri'nin Sosyal ve Ekonomik Yapısı, TTK, Ankara 1997.

Derviş Paşa, Tahdîd-i Hudûd-ı Iraniyeye Me'mûr Derviş Paşa Lâyihası, Matbaa-i Amire, İstanbul 1286.

Düstur, .Cilt 1, sene 1274.

\footnotetext{
* Belgelerin künyesi metin içerisinde verilmiştir.
} 
EPPEL, Michael, "The Demise of the Kurdish Emirates: The Impact of Ottoman Reforms and International Relations on Kurdistan during the First Half of the Nineteenth Century", Middle Eastern Studies, Vol. 44, No. 2, March 2008, s.237-258

Evliya Çelebi, Evliya Çelebi Seyahatnamesi, 4. Cilt, Dersaadet İkdam Matbaası, 1314.

GENCER, Fatih, Merkezîyetçi İdari Düzenlemeler Bağlamında Bedirhan Bey Olayı, Basılmamış Doktora Tezi, Ankara Üniversitesi Sosyal Bilimler Enstitüsü, Ankara 2010.

GÖYÜNÇ, Nejat, "Yurtluk-Ocaklık Deyimleri Hakkında", Prof. Dr. Bekir Kütükoğlu'na Armağan, İstanbul, 1991, s.267-277.

, "Osmanlı Devleti'nde Taşra Teşkilatı (Tanzimat'a Kadar)", Osmanl, 6.Cilt, Yeni Türkiye Yayınları, Ankara 1999, s.77-88.

JWAIDEH, Wadie, Kürt Milliyetçiliğinin Tarihi Kökenleri ve Gelişimi, (Çev. İsmail Çekem-Alper Duman) İletişim Yayınları, İstanbul 1999.

KILIÇ, Orhan, "Yurtluk-Ocaklık ve Hükümet Sancaklar Üzerine Bazı Tespitler", OTAM, Say1 10, Ankara 1999, s.119-137.

KODAMAN, Bayram, Osmanl Devrinde Doğu Anadolu'nun İdari Durumu, Anadolu Basın Birliği Yayınları, Ankara 1986.

KURT, Yılmaz, XVI. Yüzyılda Adana Tarihi, Basılmamış Doktora Tezi, Hacettepe Üniversitesi Sosyal Bilimler Enstitüsü, Ankara 1992.

MCDOWALL David, "Kürt Sorunu: Tarihsel Bir Bakış", Kürtler, Ed. Philip G. Kreyenbroek-Stefan Sperl, (Çev. Yavuz Alagon), Cep Kitapları, İstanbul 1992, s.14-37.

Mehmed Hurşid Paşa, Seyâhatnâme-i Hudûd, Çevrimyazı Alaattin Eser, Simurg Yayınları, İstanbul 1997.

MOLTKE, Helmuth Von, Moltke'nin Türkiye Mektupları, (Çev. Hayrullah Örs), Remzi Kitabevi, İstanbul 1999.

ÖZ, Mehmet, XVI. Yüzyılda Bitlis Sancağı: Yönetim, Nüfus ve Vergilendirme", $I X^{\text {th }}$ International Congress Of Economic And Social History Of Turkey, T.T.K., Dubrovnik 2002, s.31-54.

SHIELDS, Sarah D., Mosul Before Iraq, State University of New York Press, Albany 2000.

Sofyalı Ali Çavuş Kanunnâmesi Osmanlı Imparatorluğu'nda Toprak Tasarruf Sistemi'nin Hukuki ve Mâli Müeyyede ve Mükellefiyetleri, Hazırlayan Midhat Sertoğlu, Marmara Üniversitesi Yayınları, İstanbul 1992.

SVANIDZE, M.H., “Ahısha (Çıldır) Eyaleti’nde Defter-i Caba-i (1694-1732) Verilerine Göre Timarların Yıllık Gelirleri”, XII. Türk Tarih Kongresi, III, Ankara 1999.

Şerefhan, Şerefname Kürt Tarihi, (Çev. M. Emin Bozarslan), Hasat Yayınları, İstanbul 1990. 
TORAMAN, Ömer, Tanzimat'ın Yurtluk-Ocaklık ve Hükümet Sancaklarında Uygulanması (1839-1864), Basılmamış Doktora Tezi, Fırat Üniversitesi Sosyal Bilimler Enstitüsü, Elazığ 2010.

TURAN, Şerafettin, "XVII. Yüzyılda Osmanlı İmpratorluğu'nun İdari Taksimatı”, Atatürk Üniversitesi 1961 Yillı̆̆l, Erzurum 1963, s.201-232.

UZUN, Ahmet, Tanzimat ve Sosyal Direnişler Niş İsyanı Üzerine Ayrıntılı Bir Inceleme (1841), Eren Yayınları, İstanbul 2002.

ÜNAL, Mehmet Ali, "Osmanlı Devleti'nde Merkezi Otorite ve Taşra Teşkilatı" Osmanl, 6.Cilt, Yeni Türkiye Yayınları, Ankara 1999, s.111-121.

\section{Gazeteler}

Diyarbekir (Vilayet Gazetesi)

Takvim-i Vekayi 